\title{
Synthesis, Characterization and Thermal Stability Study of New Heterocyclic Compounds Containing 1,2,3-Triazole and 1,3,4-Thiadiazole Rings
}

\author{
RIYADH J. NAHI* and NOOR H. IMRAN \\ Department of Chemistry, College of Science, Al-Muthanna University, Iraq. \\ *Corresponding author E-mail: riyadhnahi@yahoo.com \\ http://dx.doi.org/10.13005/ojc/350128
}

(Received: November 28, 2018; Accepted: January 30, 2019)

\section{ABSTRACT}

\begin{abstract}
In the current study, a new series of 1,2,3-triazole derivatives was synthesized via copper (I) catalyzed azide-alkyne cycloaddition reaction using a series of synthesised p-substituted phenyl azides and propiolic acid. In addition, a new series of heterocyclic compounds containing 1,2,3-triazole and 1,3,4-thiadiazole ring combined in one molecule was synthesised via a condensation reaction of the synthesised 1,2,3-triazole derivatives and thiosemicarbazide in the presence of $\mathrm{POCl}_{3}$. Furthermore, the thermal behavior of these newly synthesised compounds was studied by TGA and DTG techniques.
\end{abstract}

Keywords: CuAAC, 1,2,3-triazole, 1,3,4-thiadiazole, Click reaction, Thermal stability.

\section{INTRODUCTION}

Heterocyclic compounds are a major class of organic compounds that are identified by the fact that their structures composed of at least one ring system contains at least one non-carbon atom such as oxygen $(\mathrm{O})$, nitrogen( $\mathrm{N})$ and sulpher(S) as heteroatoms $\mathrm{s}^{1-3}$. Azoles ring system containing heterocyclic compounds have a special importance due to a wide range of different applications ${ }^{4,5}$. Azole is a five-membered ring containing nitrogen atom and at least one other non-carbon atom of either nitrogen, sulphur, or oxygen ${ }^{6-8}$. Among many different azole structures, 1,4-disubstituted-1,2,3-triazole and 2-amino-1,3,4-thiadiazole derivatives (Fig. 1) have a great interest due to their promising biological and industrial applications ${ }^{9-14}$.<smiles>[R]c1cn([R])nn1</smiles><smiles>[R]c1nnc(N)s1</smiles>

$$
R, R^{\prime}, R^{\prime \prime}=\text { phenyl or alkyle group }
$$

Fig. 1. General structure of triazole and thiadiazole ring system

Thus, the synthesis and study of new 1,4-disubstituted 1,2,3-triazole and 2-amino-1,3, 4-thiadiazole derivatives have been attracting the chemists over the recent years ${ }^{15-17}$. Currently, the copper (I) catalysed azide-alkyne cycloaddition

This is an Open Access article licensed under a Creative Commons license: Attribution 4.0 International (CC- BY). Published by Oriental Scientific Publishing Company @ 2018

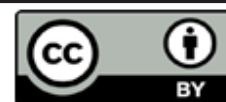


(CuAAC, also known as click reaction) that was introduced by Sharpless and et al., in 2002 is the method choice for the synthesis of 1,4-disubstituted-1,2,3-triozle derivatives ${ }^{18-20}$. While for the synthesis of 2-amino-1,3,4-thiadiazole ring system, many approaches have been reported and most of them proceed via a cyclization reaction of the intermediates such as acylthiosemecarbazide ${ }^{21-}$ ${ }^{24}$. The combination of two or more pharmacophores in one molecule is a powerful strategy in the search for discovering new applications of heterocyclic compounds $^{25}$. Thus, we planned to synthesize a series of new 1,4-disubstituted-1,2,3-triazole derivatives and then combine its 1,2,3-triazole ring system with 1,3,4-thiadiazole ring in one molecule to obtain a novel heterocyclic compounds. In the current work, the retrosynthetic pathway shows that 1,2,3-triazole and 1,3,4-thiadiazole rings are linked together directly via a covalent $\mathrm{C}-\mathrm{C}$ bond at positions C4 and C5 of their structures, respectively.

\section{EXPERIMENTAL}

\section{Chemicals and Instruments}

All starting materials and solvents that are necessary for the synthesis of the target compounds were purchased from available sources and were directly used without further purification. FT-IR spectra were recorded on an FT-IR-8400S plus spectrometer operating from $\left(4000-400 \mathrm{~cm}^{-1}\right)$ as a $\mathrm{KBr}$ disc. ${ }^{1} \mathrm{H}-$ NMR and ${ }^{13} \mathrm{C}-\mathrm{NMR}$ spectra were recorded at 500 $\mathrm{MHz}$ and $125 \mathrm{MHz}$, respectively on a Bruker AC400 spectrometer. The spectral data are mentioned using the following abbreviations for peak patterns: s-singlet, m-multiplet. The mass spectra (MS) were recorded using an Agilent 1100 Ion trap mass spectrometer operating at 70ev-. TG-DTG analysis was performed by using a Perkin Elmer TG 4000 at a temperature range $39-400^{\circ} \mathrm{C}$ in a heating rate $40^{\circ} \mathrm{C} / \mathrm{min}$ under nitrogen.

\section{Procedures}

\section{Synthesis of p-substituted phenyl azide compounds (1-5)}

All phenyl azide compounds that were used in the current work were synthesized according to the modified procedure that was described in the literature ${ }^{26}$.

General procedure for the synthesis of $1,2,3-$ triazole derivatives (6-10)

An aqueous solution of sodium ascorbate
(0.8 g, 4.0 mmole was dissolved in water $2.0 \mathrm{ml}$ ) was added to a stirred aqueous solution containing $\mathrm{CuSO}_{4} .5 \mathrm{H}_{2} \mathrm{O}(0.65 \mathrm{~g}, 3.0 \mathrm{mmole}$ was dissolved in water $2.0 \mathrm{ml}$ ). To the resulting solution, a mixture of tert-butanol:water (15.0 ml 2:1), propiolic acid (2.1 ml, 30.0 mmole) and an appropriate p-substitutedphenyl azide 1-5 (30.0 mmole) were added, sequentially. The resulting reaction mixture was slowly heated up to $50^{\circ} \mathrm{C}$ and stirred for overnight. The reaction mixture was allowed to cool into room temperature before being treated with water (100 $\mathrm{ml})$. The formed precipitate was collected by vacuum filtration, washed with diethyl ether and dried to obtain the target compounds as solid products.

Synthesis of 1-(4-methoxyphenyl)-1H-[1,2,3]triazolyl-4-carboxylic acid 6

It was prepared by using compound 1 (4.47 g, 30.0 mmole): Yield $(5.0 \mathrm{~g}, 75 \%$ ) as a brown solid. FT-IR ( $\mathrm{KBr}$ disc, $\left.\mathrm{cm}^{-1}\right)$ : $3293-2500(\mathrm{OH}$, $\mathrm{COOH}), 3151$ ( $\mathrm{CH}$-aromatic), 2930 ( $\mathrm{CH}$-aliphatic), $1730(\mathrm{C}=\mathrm{O}), 1610(\mathrm{C}=\mathrm{C}$, triazole), $1564(\mathrm{C}=\mathrm{C}, \mathrm{Ar})$ and $1437(\mathrm{~N}=\mathrm{N}) .{ }^{1} \mathrm{H}-\mathrm{NMR}\left(500 \mathrm{MHz}\right.$, DMSO-d $\left.\mathrm{d}_{6}\right): \delta=$ $3.8\left(\mathrm{~s}, 3 \mathrm{H}, \mathrm{OCH}_{3}\right), 7.1-7.8(\mathrm{~m}, 4 \mathrm{H}, \mathrm{Ar}-\mathrm{H})$ and 9.2 (s, $1 \mathrm{H}, \mathrm{C}=\mathrm{CH}$, triazole ring). $\mathrm{HPMS}^{-\mathrm{El}^{+}}(\mathrm{m} / \mathrm{z})$ : Calc. for $\mathrm{C}_{10} \mathrm{H}_{9} \mathrm{~N}_{3} \mathrm{O}_{3}=219.0$, Found $=219.1$.

Synthesis of 1-(4-methylphenyl)-1H-[1,2,3]triazol-4-yl carboxylic acid 7

It was prepared by using compound 2 (3.9 g, $30.0 \mathrm{mmole})$ : Yield (3.5 g, $50 \%$ ) as a pale brown solid. FT-IR (KBr disc, $\left.\mathrm{cm}^{-1}\right)$ : $3332-2560(-\mathrm{OH}$, $\mathrm{COOH}), 3134$ ( $\mathrm{CH}$-aromatic), 2883 ( $\mathrm{CH}$-aliphatic), $1720(\mathrm{C}=\mathrm{O}), 1640$ ( $\mathrm{C}=\mathrm{C}$, triazole), $1606(\mathrm{C}=\mathrm{C}$, $\mathrm{Ar})$ and 1471 ( $\mathrm{N}=\mathrm{N}$, triazole). 1H-NMR (500 MHz, DMSO- $\left.\mathrm{d}_{6}\right): \delta=2.3\left(\mathrm{~s}, 3 \mathrm{H}, \mathrm{CH}_{3}\right), 7.3-7.7(\mathrm{~m}, 4 \mathrm{H}, \mathrm{Ar}-\mathrm{H})$ and $8.7\left(\mathrm{~s}, 1 \mathrm{H}, \mathrm{C}=\mathrm{CH}\right.$ triazole). $\mathrm{HPMS}_{-} \mathrm{El}^{+}(\mathrm{m} / \mathrm{z})$ : Calc. for $\mathrm{C}_{10} \mathrm{H}_{9} \mathrm{~N}_{3} \mathrm{O}_{2}=203.2$, Found $=203.0$.

Synthesis of 1-(4-hydroxyphenyl)-1H-1,2,3triazoly-4-yl-carboxylic acid 8

It was prepared by using of compound 3 (4.0 g, 30.0 mmole): Yield $(6.3 \mathrm{~g}, 76 \%)$ as a black precipitate. FT-IR ( $\mathrm{KBr}$ disc, $\left.\mathrm{cm}^{-1}\right)$ : 3500-2800 (-OH, $\mathrm{COOH}), 3134$ ( $\mathrm{CH}$-aromatic), 2970 ( $\mathrm{CH}$-aliphatic), $1727(\mathrm{C}=\mathrm{O}), 1608(\mathrm{C}=\mathrm{C}$, triazole), $1573(\mathrm{C}=\mathrm{C}, \mathrm{Ar})$ and $1470(\mathrm{~N}=\mathrm{N}) .{ }^{1} \mathrm{H}-\mathrm{NMR}\left(500 \mathrm{MHz}\right.$, DMSO-d $\left.\mathrm{d}_{6}\right): \delta=$ 9.5 (s, 1H, OH-phenol ), 6.9- 7.7 (m, 4H, Ar-H) and $8.7\left(\mathrm{~s}, 1 \mathrm{H}, \mathrm{C}=\mathrm{CH}\right.$, triazole). HPMS-El ${ }^{+}(\mathrm{m} / \mathrm{z})$ : Calc.

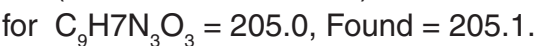


Synthesis of 1-(4-bromophenyl)-1H-1,2,3-triazol4-yl carboxylic acid 9

It was prepared by using compound 4 (5.9 g, 30.0 mmole):Yield (7.5 g, $93 \%$ ) as a brown precipitate. FT-IR ( $\mathrm{KBr}$ disc, $\left.\mathrm{cm}^{-1}\right)$ : 3475-2400 $(\mathrm{OH}$, $\mathrm{COOH}), 3028$ ( $\mathrm{CH}$-aromatic), 2930 ( $\mathrm{CH}$-aliphatic), $1695(\mathrm{C}=\mathrm{O}), 1614$ ( $\mathrm{C}=\mathrm{C}$, triazole), 1585 ( $\mathrm{C}=\mathrm{C}, \mathrm{Ar})$, $1402(\mathrm{~N}=\mathrm{N})$ and $734(\mathrm{C}-\mathrm{Br}) .{ }^{1} \mathrm{H}-\mathrm{NMR}(500 \mathrm{MHz}$, DMSO- $\left.\mathrm{d}_{6}\right): \delta=7-8.3(\mathrm{~m}, 4 \mathrm{H}, \mathrm{Ar}-\mathrm{H}), 8.9(\mathrm{~s}, 1 \mathrm{H}, \mathrm{C}=\mathrm{CH}$, triazole ring). $\mathrm{HPMS}-\mathrm{El}^{+}(\mathrm{m} / \mathrm{z})$ : Calc. for $\mathrm{C}_{9} \mathrm{H}_{6} \mathrm{~N}_{3} \mathrm{O}_{2} \mathrm{Br}$ $=268.0$, Found $=267.0$

Synthesis of 1-(4-chlorophenyl)-1H-1,2,3-triazol4-yl carboxylic acid 10

It was prepared by using compound 5 (4.6 g, $30.0 \mathrm{mmole})$ : Yield (6 g, $89 \%$ ) as a wight precipitate. FT-IR ( $\mathrm{KBr}$ disc, $\left.\mathrm{cm}^{-1}\right)$ : 3468-2570 (-OH, $\mathrm{COOH}), 3100$ ( $\mathrm{CH}$-aromatic), 2852 ( $\mathrm{CH}$-aliphatic), $1702(\mathrm{C}=\mathrm{O}), 1552(\mathrm{C}=\mathrm{C}$, triazole), $1500(\mathrm{C}=\mathrm{C}, \mathrm{Ar})$ and $1431(\mathrm{~N}=\mathrm{N}) .{ }^{1} \mathrm{H}-\mathrm{NMR}\left(500 \mathrm{MHz}, \mathrm{DMSO}-\mathrm{d}_{6}\right): \delta=$ 7.7-8.1 (m, 4H, Ar-H), $8.8(\mathrm{~s}, 1 \mathrm{H}, \mathrm{C}=\mathrm{CH}$, triazole ring). $\mathrm{HPMS}-\mathrm{El}^{+}(\mathrm{m} / \mathrm{z})$ : Calc. for $\mathrm{C}_{9} \mathrm{H}_{6} \mathrm{~N}_{3} \mathrm{O}_{2} \mathrm{Cl}=223.02$, Found $=223.0$.

General procedure for synthesis of $1,3,4-$ Thiadiazoles derivatives (11-15)

An appropriate 1,2,3-triazole derivative 6-10 (20.0 mmole) and thiosemicarbazide $(1.8 \mathrm{~g}$, 20.0 mmole) were dissolved in $\mathrm{POCl}_{3}(30.0 \mathrm{ml})$. The resulting reaction mixture was refluxed for 7.0 hours. The reaction mixture was then allowed to cool into room temperature before being slowly poured onto crush-ice $(200 \mathrm{~g})$. The resulting solution was stirred for 15 min before being treated carefully with an aqueous solution of sodium hydroxide $50 \%$. The precipitate was then collected by filtration under vacuum, washed with water and dried to obtained the target compounds as solid products.

Synthesis of 2-amino-5-[1-(4-methoxy phenyl)1H-1,2,3-triazol-4-yl]-1,3,4 thiadiazole 11

It was prepared by using compound 6 (4.3 g, 20.0 mmole): Yield (5.0 g, $92 \%)$ as a dark green precipitate. FT-IR (KBr disc, $\left.\mathrm{cm}^{-1}\right): 3287-3130\left(-\mathrm{NH}_{2}\right)$, 2962 ( $\mathrm{CH}$-aromatic), 2864 ( $\mathrm{CH}$-aliphatic), $1665(-\mathrm{C}=\mathrm{N}-)$, $1612(\mathrm{C}=\mathrm{C}$, triazole $), 1518(\mathrm{C}=\mathrm{C}, \mathrm{Ar})$ and $1440(-\mathrm{N}=\mathrm{N})$. ${ }^{1} \mathrm{H}-\mathrm{NMR}\left(500 \mathrm{MHz}, \mathrm{DMSO}-\mathrm{d}_{6}\right): \delta=3.8\left(\mathrm{~s}, 3 \mathrm{H}, \mathrm{OCH}_{3}\right)$, 8.1-8.3 (m, 4H, Ar-H) and $8.4(\mathrm{~s}, 1 \mathrm{H}, \mathrm{C}=\mathrm{CH}$, triazole ring). ${ }^{13} \mathrm{C}-\mathrm{NMR}\left(125 \mathrm{MHz}, \mathrm{DMSO}, \mathrm{d}_{6}\right): \delta=160,140$, 132, 130, 125, 123, 120, 115 and 56. HPMSEl$^{+}(\mathrm{m} / \mathrm{z})$ : Calc. for $\mathrm{C}_{11} \mathrm{H}_{10} \mathrm{~N}_{6} \mathrm{SO}=274.0$, Found $=274.1$.
Synthesis of 2-amino-5-[1-(4-methylphenyl)-1H1,2,3-triazol-4-yl]-1,3,4-thiadiazole 12

It was prepared by using compound 7 (4.0 g, 20.0 mmole): Yield (3.5 g, yield $78 \%$ ) as a brown precipitate. FT-IR (KBr disc, cm $\left.{ }^{-1}\right)$ : $3414-3100\left(-\mathrm{NH}_{2}\right)$, 3144 (CH-aromatic), 2937 ( $\mathrm{CH}$-aliphatic), 1647 $(-\mathrm{C}=\mathrm{N}), 1610(\mathrm{C}=\mathrm{C}$, triazole $), 1504(\mathrm{C}=\mathrm{C}, \mathrm{Ar})$ and $1440\left(-\mathrm{N}=\mathrm{N}\right.$ - triazole). ${ }^{1} \mathrm{H}-\mathrm{NMR}(500 \mathrm{MHz}, \mathrm{DMSO}$, $\left.\mathrm{d}_{6}\right) \delta=2.4\left(\mathrm{~s}, 3 \mathrm{H}, \mathrm{CH}_{3}\right), 6.9-7.7(\mathrm{~m}, 4 \mathrm{H}, \mathrm{Ar}-\mathrm{H})$ and 9.7 (s, $1 \mathrm{H}, \mathrm{C}=\mathrm{CH}$, triazole ring). ${ }^{13} \mathrm{C}-\mathrm{NMR}(125 \mathrm{MHz}$, DMSO-d $\left.{ }_{6}\right): \delta=165,154,147.5,134,132,120,115$ and 110. HPMS-El+ $(\mathrm{m} / \mathrm{z})$ : Calc. for $\mathrm{C}_{11} \mathrm{H}_{10} \mathrm{~N}_{6} \mathrm{~S}=$ 258.0, Found $=258.0$.

Synthesis of 2-amino-5-[1-(4-hydroxyphenyl)-1H1,2,3-triazol-4-yl]-1,3,4-thiadiazole 13

It was prepared by using compound 8 (4.1 g, 20.0 mmole): Yield (4.6 g, $88 \%)$ as a black precipitate. FT-IR ( $\mathrm{KBr}$ disc, $\left.\mathrm{cm}^{-1}\right)$ : 3445-3150 $\left(-\mathrm{NH}_{2}\right), 3306(-\mathrm{OH}), 3010(\mathrm{CH}$-aromatic), 2744 (CH-aliphatic), 1643 (-N=C-), $1606(\mathrm{C}=\mathrm{C}$, triazole) and $1512(\mathrm{C}=\mathrm{C}, \mathrm{Ar}) .{ }^{1} \mathrm{H}-\mathrm{NMR}\left(500 \mathrm{MHz}, \mathrm{DMSO}-\mathrm{d}_{6}\right)$ : $\delta=9.4(\mathrm{~s}, 1 \mathrm{H}, \mathrm{OH}$ - phenol), 7.3-8 (m, 4H, Ar-H) and 9.4 (s, $1 \mathrm{H}, \mathrm{C}=\mathrm{CH}$, triazole). ${ }^{13} \mathrm{C}-\mathrm{NMR}(125 \mathrm{MHz}$, DMSO-d $\left.{ }_{6}\right): \delta=165,152,154.2,133,130,120,122.3$ and 116.2. $\mathrm{HPMS}-\mathrm{El}^{+}(\mathrm{m} / \mathrm{z})$ : Calc. for $\mathrm{C}_{10} \mathrm{H}_{8} \mathrm{~N}_{6} \mathrm{SO}=$ 260.0 , Found $=260.0$.

Synthesis of 2-amino-5-[1-(4-bromophenyl)-1H1,2,3-triazol-4-yl]-1,3,4-thiadiazole 14

It was prepared by using compound 9 (5.3 g, 20.0 mmole): Yield $(5.5 \mathrm{~g}, 85 \%)$ as a gray precipitate. FT-IR ( $\mathrm{KBr}$ disc, $\mathrm{cm}^{-1}$ ): 3400-3320 $\left(\mathrm{NH}_{2}\right), 3009$ ( $\mathrm{CH}$-aromatic), 2901 ( $\mathrm{CH}$-aliphatic), 1653 (-N=C-), 1620 (C=C, triazole), 1552 (C=C, Ar) and $1420(-\mathrm{N}=\mathrm{N}-) \cdot{ }^{1} \mathrm{H}-\mathrm{NMR}\left(500 \mathrm{MHz}, \mathrm{DMSO}-\mathrm{d}_{6}\right)$ : $\delta=7.5-8(\mathrm{~m}, 4 \mathrm{H}, \mathrm{Ar}-\mathrm{H}), 9.8(\mathrm{~s}, 1 \mathrm{H}, \mathrm{C}=\mathrm{CH}$, triazole ring). ${ }^{13} \mathrm{C}-\mathrm{NMR}(125 \mathrm{MHz}$, DMSO-d $): \delta=168,160$, 148, 142, 136, 133, 123 and 120. HPMS-El+ $(\mathrm{m} / \mathrm{z})$ : Calc. for $\mathrm{C}_{10} \mathrm{H}_{7} \mathrm{~N}_{6} \mathrm{SBr}=323.9$, Found $=324.0$.

\section{Synthesis of 2-amino-5-[1-(4-chlorophenyl)-1H-} 1,2,3-triazol-4-yl]-1,3,4-thiadiazole 15

It was prepared by using the compound 10 (5.3 g, 20 mmole): Yield (5.0 g, $90 \%$ ) as a dark green precipitate. FT-IR ( $\mathrm{KBr}$ disc, $\left.\mathrm{cm}^{-1}\right)$ : 3466-3120 $\left(\mathrm{NH}_{2}\right), 2936$ (CH-aliphatic), 1676 (-N=C-), 1590 $(\mathrm{C}=\mathrm{C}$, triazole), $1502(\mathrm{C}=\mathrm{C}, \mathrm{Ar})$ and $1417(-\mathrm{N}=\mathrm{N}-)$. ${ }^{1} \mathrm{H}-\mathrm{NMR}\left(500 \mathrm{MHz}, \mathrm{DMSO}-\mathrm{d}_{6}\right): \delta=7.4-8.1(\mathrm{~m}, 4 \mathrm{H}$, Ar-H) and 9.3 (s, $1 \mathrm{H}, \mathrm{C}=\mathrm{CH}$, triazole). ${ }^{13} \mathrm{C}-\mathrm{NMR}$ 
$\left(125 \mathrm{MHz}, \mathrm{DMSO}-\mathrm{d}_{6}\right): \delta=161,165,152,145$, 135, 133, 123 and 120. HPMS-El ${ }^{+}(\mathrm{m} / \mathrm{z})$ : Calc. for $\mathrm{C}_{10} \mathrm{H}_{7} \mathrm{~N}_{6} \mathrm{ClS}=278.7$, Found $=278.0$

\section{RESULTS AND DISCUSSION}

\section{Chemistry}

In the current project, a series of rich and poor-electron p-substituted phenyl azide compounds 1-5 was designed as an azido component for CuAAC reaction. Choosing of different substituted phenyl azides is to investigate the effects of a structural variation on their chemical reactivity towards click reaction and the thermal behavior of the synthesized heterocyclic compounds $6-15$. The intermediates azide compounds 1-5 were synthesized via reaction of diazonium salts with sodium azide (Scheme 1). Having the target azido compounds 1-5, we turned our efforts to combine them with the commercially available propiolic acid under click reaction conditions. The synthesis route of 1-(4-substituted phenyl)- $1 \mathrm{H}$ 1,2,3-triazol-4-yl-carboxylic acid derivatives 6-10 is illustrated in Scheme1. This synthetic route involved addition of propiolic acid and appropriate azide $1-5$ to a solution of tert-butanol: water $(2: 1 \mathrm{v} / \mathrm{v})$ containing $\mathrm{CuSO}_{4} \cdot 5 \mathrm{H}_{2} \mathrm{O}$ and sodium ascorbate. The latter is a reducing agent to generate in situ $\mathrm{Cu}(\mathrm{I})$ species that are required to perform click reaction.

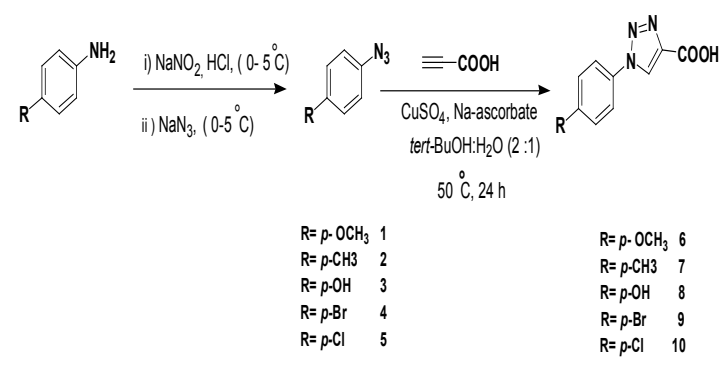

Scheme 1. Synthesis of 1,2,3-triazole derivatives (6-10)

In this synthetic pathway, the reaction mixture was first left to stir at room temperature for overnight. However, the target compounds were obtained in a very low yield. An attempt to improve this low yield revealed that the standard click tion solvent tert-butanol: water (1:1) is not enough to dissolve all amounts of the azido components 1-5. Once the ratio of the solvent tert-butanol:water was changed to $(2: 1 \mathrm{v} / \mathrm{v})$ with heating up to $50^{\circ} \mathrm{C}$, the target compounds 6-10 were obtained in relatively high yields. Our synthesis route highlighted a simple work up and the products were pure enough without need to further purifications by column chromatography. The structures of the newly synthesized compounds were characterized by FT-IR, ${ }^{1} \mathrm{H}-\mathrm{NMR}$ and Mass spectra. Moreover, choosing of propiolic acid as an alkyne component in CuAAC reaction takes advantage that the synthesised 1,2,3-triazole 6-10 containing a carboxyl function group attached directly at C4 position of 1,2,3-triaozle ring system. So, it can be exploited to combine 1,2,3-triazole ring system with different structures. In the current work, we are interested in the combination of 1,2,3-triazole ring with 1,3,4-thiadiazole ring in one molecule. The most widely applicable route for the synthesis of 1,3,4-thiadiazole ring system is the thermal acid or base catalyzed dehydro-cyclization of their corresponding acylthiosemicarbazone to construct 2-amino-1,3,4-thiadiazole ring system ${ }^{27,28}$. Therefore, the synthesised 1,2,3-triazole derivatives 6-10 and thiosemicarbazide were the key starting materials for the synthesis of the target compounds 11-15. The cyclocondensation of thiosemicarbazide with 1,2,3triaozle derivatives compounds $6-10$ in the presence of $\mathrm{POCl}_{3}$ under reflux conditions afforded a series of new heterocyclic compounds containing 1,2,3-triazole and 1,3,4-thiadaizole ring systems combined in one molecule 11-15 as described in Scheme 2.

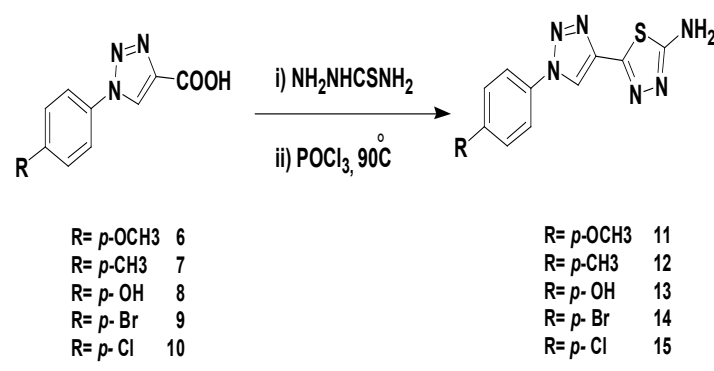

Scheme 2. Synthesis of 1,3,4-thiadiazole derivatives (11-15)

Importantly, the work up of this reaction involved treating the resulting crude solutions with a solution of $\mathrm{NaOH}(50 \%)$ before being filtered. This step is necessary to remove any remaining unreacted amount of starting materials specially compounds $6-10$, thereby leading to give the target compounds $11-15$ are pure enough without any need to further purification by column chromatography. The structures of the newly synthesized compounds were characterized by FT-IR, ${ }^{1} \mathrm{H}$-NMR, ${ }^{13} \mathrm{C}$-NMR and Mass spectra.

Thermal stability study of the synthesised compounds (6-15)

Currently, thermal analysis has been 
become an important tool to study the thermal stability of important products such as organic compounds, polymers and pharmaceuticals ${ }^{29}$. In the current study, the thermal stability studied by TG and DTG techniques. Thermogravimetry (TG) is one of the basic and useful analytical methods of thermal analysis that are used for recording weight lossing of a tested sample as a function of temperature or time in a heated environment ${ }^{30}$. While, by DTG curve, the area of the peak ( $T_{\text {initial }}$, $T_{\text {final }}$ ) is directly proportional to the mass loss over the same temperature range and the DTG peak high at any temperature gives the rate of mass loss
(dm/dT in $\mathrm{mg} / \mathrm{min}$ unit) ${ }^{31,32}$. Therefore, the knowledge of the DTG curve helps to permit the direct application of the rate function of the change in the weight of the target sample to the study of phenomena occurring during thermogravimetric analysis. Practically, depending on the nature of the p-rich or poorelectron substituted phenyl that is attached to N1-position of 1,2,3-triazole ring of compounds 6, 7, 8, 9 and 10.TG-DTG measurements revealed that these compounds are thermally stable up to 250, 240, 275, 205 and $270^{\circ} \mathrm{C}$, respectively. Followed a single step decomposition as shown in Fig. 2, 3 and Table1.

Table 1: TG/DTG data of compounds 6-10

\begin{tabular}{|c|c|c|c|c|c|}
\hline \multirow[t]{2}{*}{ No } & \multirow[t]{2}{*}{ Structure } & \multicolumn{2}{|c|}{ Decomposition temperature range ${ }^{\circ} \mathrm{C}$} & \multirow{2}{*}{$\begin{array}{l}\text { Maximum mass } \\
\text { lossing temperature }{ }^{\circ} \mathrm{C}\end{array}$} & \multirow{2}{*}{$\begin{array}{l}\text { Losing } \\
\text { weight } \%\end{array}$} \\
\hline & & $\mathrm{T}_{\text {initial }}$ & $\mathrm{T}_{\text {final }}$ & & \\
\hline 6 & & 253 & 402 & 350.7 & 42.9 \\
\hline 7 & & 244 & 272 & 259.8 & 46 \\
\hline 8 & & 277 & 317 & 290.5 & 42.4 \\
\hline 9 & & 209 & 278 & 233.09 & 29.4 \\
\hline 10 & & 271 & 390 & 361.2 & 41.6 \\
\hline
\end{tabular}

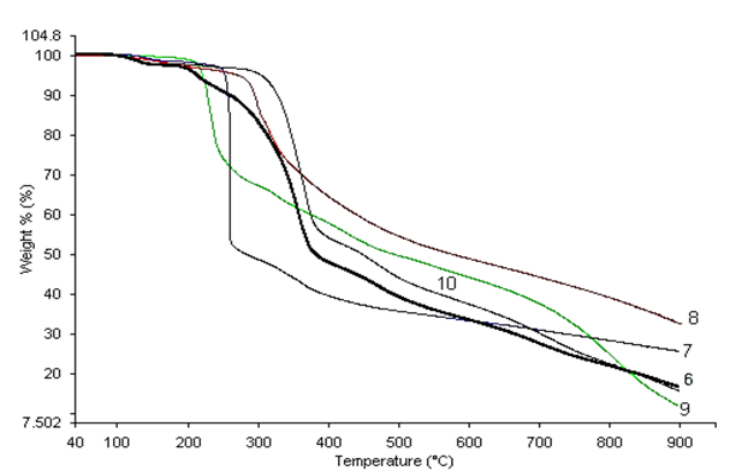

Fig. 2. TG curves for compounds (6-10)

While, TG-DTG measurements that were recorded for compounds 11-15 indicted that these compounds are thermally behaved in the same manner that was described for their precursors

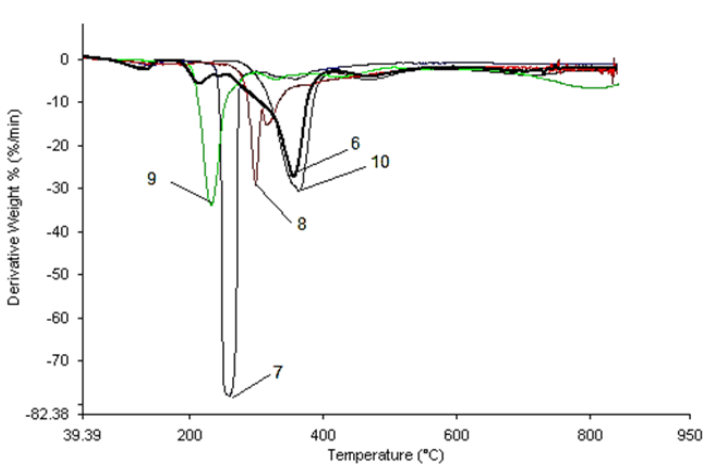

Fig. 3. DTG curves for compounds (6-10)

6-10. All compounds 11, 12, 13, 14 and 15 are thermally stable up to $260,205,279,280$ and $274^{\circ} \mathrm{C}$, respectively, followed with a single step decomposition as shown in Fig. 4, 5 and Table 2. 
Table 2: TG/DTG data of compounds 11-15

\begin{tabular}{|c|c|c|c|c|c|}
\hline \multirow[t]{2}{*}{$\overline{\text { No }}$} & \multirow[t]{2}{*}{ Structure } & \multicolumn{2}{|c|}{ Decomposition temperature range ${ }^{\circ} \mathrm{C}$} & \multirow{2}{*}{$\begin{array}{c}\text { Maximum mass } \\
\text { lossing temperature }{ }^{\circ} \mathrm{C}\end{array}$} & \multirow{2}{*}{$\begin{array}{l}\text { Losing } \\
\text { weight } \%\end{array}$} \\
\hline & & $\mathrm{T}_{\text {initial }}$ & $T_{\text {final }}$ & & \\
\hline 11 & & 260 & 397 & 355.2 & 35.8 \\
\hline 12 & & 205 & 410 & 360.1 & 25.2 \\
\hline 13 & & 279 & 358 & 296.5 & 24.6 \\
\hline 14 & & 280 & 350 & 313.2 & 25.2 \\
\hline 15 & & 274 & 384 & 324.2 & 31.7 \\
\hline
\end{tabular}

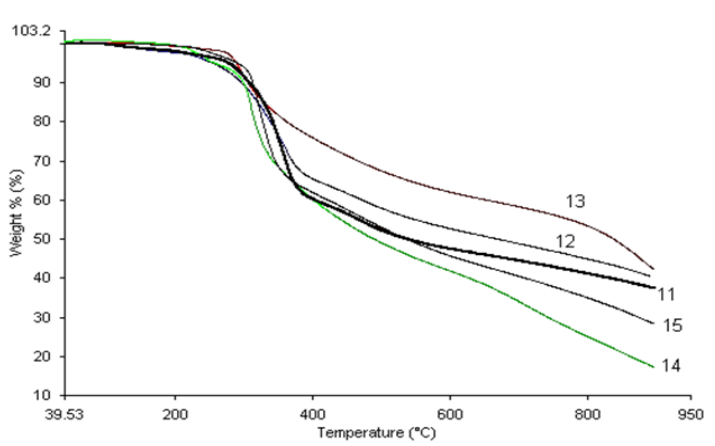

Fig. 4. TG curves for compounds (11-15)

\section{CONCLUSION}

In conclusion, all poor-rich electron phenyl azide compounds were successfully reacted with propiolic acid under click reaction conditions. Since the formed compounds containing a carboxyl functional group, it used as a key to synthesise a series of new heterocyclic compounds containing 1,2,3-triazole and 1,3,4-thiadiazole rings in one molecule. Furthermore,

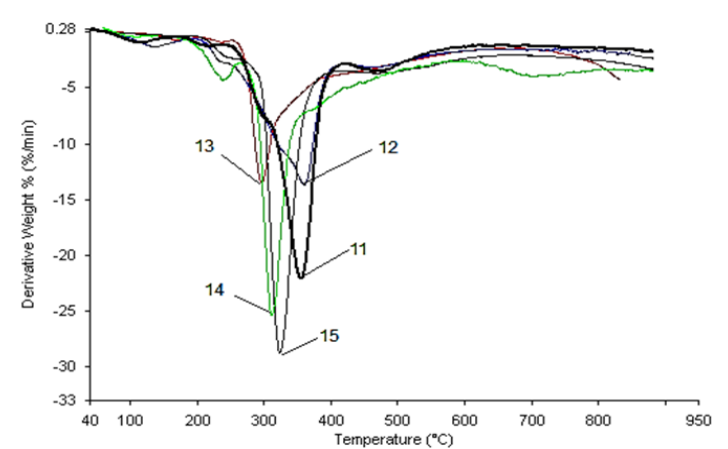

Fig. 5. DTG curves for compounds (11-15)

all synthesized heterocyclic compounds displayed a relatively good thermal stability.

\section{ACKNOWLEDGMENT}

The authors would like to thank the department of chemistry/College of Science /AI-Muthanna University for the facilities during doing this work.

\section{REFERANCES}

1. Martins, P.; Jesus, J.; Santos, S.; Raposo, L. R.; Rodrigues, C. R.; Baptista, P. V.; Fernandes, A R. Molecules., 2015. 20, (9), 16852-16891.

2. Seeka, S.; Narsimha, S.; Jyostna, S.; Reddy, N.V. Int. J. Pharmacol. Pharm. Sci., 2015. 2, (4), 26-32.

3. Singh, A. K.; Mishra, G.; Jyoti, K. Int. J.
ChemTech Res., 2011, 1, (5), 44-49.

4. Rajam, S.; StellaP, C. R.; Dileepan, G. B. J. Chem. Pharm. Res., 2016, 8(5), 505-526.

5. Yamamoto, T.; Muto, K.; Komiyama, M.; Canivet, J.; Yamaguchi, J.; Itami, K. Chem. Eur. J., 2011, 17(36), 10113-10122. 
6. Otero, N.; Estévez, L.; Mandado, M.; Mosquera, R. A. Eur. J. Org. Chem., 2012. 10(12), 2403-2413.

7. Pawełczyk, A.; Sowa-Kasprzak, K.; Zaprutko, L. ECSOC., 2017, 1, 1-4.

8. Jiang, J.;Zou, H.; Dong, Q.;Wang, R.; Lu, L.; Zhu, Y.; He, W. J. Org. Chem., 2016, 81(1), 51-56.

9. Rezki, N.; Al-Yahyawi, A. M.; Bardaweel, S. K.; Al-Blewi, F. F.; Aouad, M.R. Molecules., 2015, 20(9), 16048-16067.

10. Stefani, H. A.; Silva, N.C. S.; Manarin, F.; Lüdtke, D. S.; Zukerman-Schpector, J.; Madureira, L. S.; Tiekink, E. R. T. Tetrahedron Letters., 2012, 53(14), 1742-1747.

11. Hu, Y.; Li, C.; Wang, X.; Yang, Y.; Zhu, H. Chem. Rev., 2014, 114(10), 5572-5610.

12. Abdelriheem, NA.;Mohamed, AMM.;Abdelhamid, AO. Molecules., 2017, 22(268), 1-16.

13. Altintop, M.D.; Ozdemir, A.; Kucukoglu, K.; TuranZitouni, G.; Nadaroglu, H.; Kaplancikli, Z.A. J. Enzyme Inhib. Med. Chem., 2015, 30 (1), 32-37.

14. Altintop, MD.; Can, ÖD.; Demir Özkay, Ü.; Kaplancikl, ZA. Molecules., 2016, 21(8), 1-10.

15. Hamama, S.W.; Gouda, M. A.; Abd El-Wahab, M. H.; Zoorob, H. H. J. Heterocyclic Chem., 2014, 51, 1558 -1581.

16. Serban, G.; Stanasel, O.; Serban, E.; Bota, S. Drug Design, Development and Therapy., 2018, 12, 1545-1566.

17. Kumar, A. S.; Ghule, V.D.; Subrahmanyam, S.; Sahoo, A. K. Chem. Eur. J., 2013, 19(2), 509-518.

18. Pengju, Ji.; Atherton, J. H.; I. Page, M. Org. Biomol. Chem., 2012, 10(39), 7965-7969.

19. Heravi, M. M.; Tamimi, M.; Yahyavi, H.;
Hosseinnejad, T. Curr. Org. Chem., 2016, 20 (15), 1591-1647.

20. Singh, M. S.; Chowdhury, S.; Koley, S. Tetrahedron., 2016, 72(35), 5257-5283.

21. El-Sadek, M. M.; Hassan, S.Y.; Abdelwahab, H.E.; Yacout, G. A. Molecules., 2012, 17(7), 8378-8396.

22. Hu, Y.; Li, C.Y.; Wang, X.; Yang, Y.; Zhu, H. Chem. Rev., 2014, 114(10), 5572-5610.

23. Niu, P.; Kang, J.; Tian, X.; Song, L.; Liu, H.; Wu, J.; Yu, W. J. Org. Chem., 2015, 80(2), 1018-1024.

24. Parmar, KC.; Umrigar, N. H. J. Chem. Pharm. Res., 2017, 9(6), 202-214.

25. Kaserer, T.; Beck, K.R.; Akram, M.; Odermatt, A.; Schuster, D.; Willett, P. Molecules., 2015, 20(12), 22799-22832.

26. Lima-Neto, RG.; Cavalcante, NNM.; Srivastava, RM.; Mendonça Junior, F. J. B.; Wanderley, G. A. Molecules., 2012, 17(5), 5882-5892.

27. Manimaran, T.; Anand Raj, M.; Jishala, MI.; Gopalasatheeskumarlnt, K. J. Pharm. Anal. Res., 2017, 6(2), 222-231.

28. Al-Amiery, A. A.; Musa, A. Y.; Kadhum, A. A. H.; Mohamad, A. B. Molecules., 2011, 16 (8), 6833-6843.

29. Abd El-Halim, H. F.; Omar, MM.; Mohamed, G. G. Spectrochim. Acta A., 2011, 78, (1), 36-44.

30. Feist, M. ChemTexts., 2015, 1(8), 1-12.

31. Feist, M.; Teinz, K.; Manuel, SR.; Kemnitz, E. Thermochimica Acta., 2011, 524, 170-178.

32. Rostek, E.; Biernat, K. J. Sustainable Develop. Energy, Water and Environ. Systems., 2013, 1(2), 163-171. 